profession, which is often regarded as very conservative, is efficiently organised for medico-political action upon trade-union lines. The representative meeting has no executive functions, but its resolutions, confirmed in general meeting, are binding upon the council, which is elected by a postal vote upon a proportional representative basis. The association has about 25,000 members, the number of medical men in the United Kingdom being about 33,000.

The provision of sanatorium benefit met with less unfavourable consideration, the working conditions of this portion of the Act being in part determined by those of existing institutions, and being therefore less unacceptable to the members; nevertheless, the opinion was freely expressed that the advantages to consumptives anticipated by the lay Press would prove to be largely illusory.

The scientific business of the association, which did not commence until July 24, extended over three days, during which period, however, only the mornings were occupied with sectional meetings. The time of the sectional meetings was largely occupied with discussions on subjects of interest, the number of papers read being somewhat small. The difficulties attending medical research work were abundantly illustrated, as was also the important part played by the University of Liverpool in the advancement of medical knowledge, particularly in the domain of physiology, pathology, and tropical medicine.

To give an adequate idea of the character and extent of recent scientific advances in medicine, as exhibited in the proceedings of the sections, is impossible within the limits of the present article, but by way of illustration brief reference may be made to the work of two of the sections.

In the Section of Physiology, Prof. Benjamin Moore, F.R.S. (Liverpool), contributed a paper dealing with the importance of substances present in minute anount in food, the value of which cannot be estimated by the amount of heat energy which they contain and can yield to the body on oxidation. This was first observed in respect of inorganic salts, which were at one time regarded as inert constituents, or even as protein impurities, but are now known to be important activators to the functions of the organic constituents, without which these become inert. In the hormones, or internal secretions of the body, organic substances are found which, in minute amounts, stimulate and activate in a very specific way definite tissues and cause changes in nutrition out of all proportion to their mass. From recent researches it would appear to be a general rule, especially seen in man, that some form of stimulus is almost essential, and that, if abstinence or restriction is practised in one form, some other form must be substituted. The various cereal foods which appear so simple in nature also contain basic bodies in minute quantities which exert a powerful stimulant action upon the nervous tissues, and in their complete withdrawal certain wellmarked results appear which are intimately connected with diseases of nutrition. These substances appear to be formed in the peripheral layers and are removed in certain methods of preparing the cereals. The effect of removal upon a diet of cereals is exhibited by beriberi in man and by the now well-known rapidly fatal illness, characterised by muscular paralysis and incoordination, first shown by Eijkman to be readily producible in pigeons. In both cases the addition of the defective substance is speedily followed by recovery. One of the active substances concerned in the case of rice has been isolated by Casimir Funk (London), and has been shown to be of relatively simple chemical constitution.

Considerable interest was exhibited in the Section of Tropical Medicine, where a series of papers, illustrating incidentally the small beginnings of exact knowledge, were contributed by Stephens and Fantham (Liverpool), Kleine (South Africa), Mesnil (Paris), Kinghorn and Yorke (Rhodesia), and Wolbach and Bruger (Boston), dealing with sleeping sickness, which at the present time, as is well known, seriously menaces the future of colonial development in tropical Africa. Another series of researches, also cosmopolitan in character, by Duval (New Orleans), Bayon (London), Marchoux (Paris), Dean (Aberdeen), and Minett (Demerara), dealt with the organisms which have been isolated from leprous lesions, the relation of which to human leprosy and to rat leprosy is now receiving the attention of scientific investigators. Considerable diversity of opinion, in respect of the significance of experimental investigations, was observable, due in part to the limitations of research.

An excellent exhibition of scientific apparatus and of synthetic products was provided, the interest of which was considerably augmented by the scientific knowledge possessed by many of the exhibitors.

\section{PHYSIOGRAPHY OF THE PRAIRIES AND NORTH-EASTERN AUSTRALIA.}

THE much-debated problem why the prairies of the United States are treeless is, according to an article by Mr. B. Shimek in the Bulletin of the State University of Iowa, new series, No. 35, essentially one for the botanist, since, despite variation in surface-conditions, there is comparative uniformity in the flora throughout the area. Summarising the available evidence, the author concludes that exposure to evaporation, as determined by temperature, wind, and topography, is the primary factor in the development of the treeless condition, and that the flora persists in the exposed areas because of its xerophytic character. On the other hand, rainfall and drainage, although important as determining the amount of moisture in air and soil, are only a secondary factor, as they may be equal in the forested and treeless areas; while the nature of the soil and the geological formation affect the matter only so far as they induce conservation of water. Prairie-fires were an effect rather than a cause, and when they did act in the latter sense were but local, while seed-dispersal, although accounting for the growth of plants, will not explain the origin and presence of the flora as a whole. Finally, such agencies as the bison and the action of the sea do not enter into the problem at all.

Passing from the prairies of the Wild West to the coast districts of north-eastern Australia, reference may be made to a remarkably interesting article on the physiography of that area communicated to the Sitzungsberichte der $\mathrm{kgl}$. böhm. Ges. der Wissenschaften for 19II, art. 32 , by Dr. J. V. Danes, who recently spent several months in the country. As is well known, this part of Australia is remarkable on account of the fact that the great "Divide" is on the rim, instead of in the heart, of the continent, where it is formed by the uniform littoral wall of an old peneplane inclining slightly to the west, and abruptly falling to the eastern coast; and likewise for the sudden flexures in the river-valleys, and their abnormal slope, accompanied by waterfalls, as they approach the sea.

Another feature is the presence of shallow lakes in an undulating area, which have been regarded by other observers as indicative of the recent formation of a new "divide," being, in fact, "cut-offs" from the head-waters of the original rivers.

While admitting a former great extension of the NO. $223 \mathrm{I}$, VOL. 89] 
Australian continent-as exemplified by the theory of a peneplane extending from New Guinea to Tasmania -Dr. Daneš cannot bring himself to accept, at all events in their entirety, the views of previous observers with regard to the establishment of present conditions. To put the matter briefly, he considers that the peneplane of eastern Australia was divided into a number of basins devoid of outlet and occupied by shallow lakes, which tended to dry up during prolonged drought, such lakes being, therefore, of independent origin, and not "cut-offs." Climatic conditions were then much more favourable to the development of an abundant flora and fauna, which will explain the occurrence of the great extinct marsupials in the Pleistocene beds of Darling Downs. Desiccation of the area led to the death of the old fauna and flora.

In this respect he is in accord with Dr. A. C. Gregory, who wrote that "there is no trace either in the Darling Downs or any other part of Queensland of any violent convulsion of nature which would be adequate to cause the total destruction of the diprotodon and co-occupants of the country, and it seems most probable that their extinction resulted from a gradual change of climate and more effectual drainage of the ivatercourses-aided, perhaps, by some slight changes in level."

R. I..

\section{SOME ENGLISH PUBLICATIONS ON AGRICULTURAL SCIENCE.}

$\bigcirc^{\mathrm{F}}$ the numerous agricultural periodicals and journals published in Great Britain none is more important than the Journal of the Royal Agricultural Society, which comes out annually, and gives some account of advances that have been made in the practice or the science of agriculture during recent times. The current issue is the seventy-second volume, publication having been continuous ever since 1840; although smaller in bulk than some of the old volumes, it well maintains the high standard set by Mr. Mackenzie when he took over the editorship some four years ago.

The opening article, by Prof. T. B. Wood, gives an able summary of our present knowledge of the composition and food value of bread. Probably no single product possesses greater interest to the agriculturist than wheat, even though in many cases it has fallen to the level of a by-product, and has ceased to be the staple of the farm. The advances in milling technique have led to considerable alterations in the relative values of the different wheats; formerly a white wheat possessed chief value because it gave the whitest flour, while now a red wheat is equally useful. Recently the hard wheats of great strength have come into favour, because of their capacity for making a large loaf; these wheats are more economically produced in continental areas-Canada, the United States, \&c.-than here. In general, however, flour is made from a mixture of wheats carefully graded to secure certain definite characters. This blended flour does not show the deficiencies in protein, \&c.. that an unblended flour would show in comparison with the whole grain, so that a usual argument in favour of brown bread loses much of its force. This paper is followed by one on the milling of wheat, by Mr. A. E. Humphries. Of the other papers, one on green crops, by Prof. Malden, is of more than technical interest, and shows that the ordinary agriculturist does not utilise as fully as he might certain plants that would be very useful to him.

An interesting investigation on ropy milk has been published by Mr. J. Golding in the Journal of the Board of Agriculture (No. I2). This is a disease of milk brought about by bacteria, and causing the milk to take on a rope-like form when poured from a jug, or to draw out into long threads, sometimes a yard in length, when taken up in a spoon. Several bacteria are known that can effect this change, and one of them, the Bacillus lactis viscosus of Adametz, was investigated in some detail.

The possibility of growing tobacco in England is being investigated at the Wye Agricultural College by Mr. G. H. Garrad. It is proposed to grow the crop for the sake of its nicotine, which forms an admirable insecticide, but is at present very costly for the grower. Messrs. Garrad and Edwardes-Ker conclude that extraction of the nicotine from the leaf is not necessary, satisfactory washes being obtained when the leaves are simply macerated in water. Permission to grow tobacco for this purpose could not be obtained unless the leaves could be denatured so thoroughly as to be unsmokable. The authors are at present at work endeavouring to find some method of doing this.

\section{GRANTS FOR SCIENTIFIC PURPOSES FROM THE DEVELOPMENT FUND.}

A MEMORANDUM showing advances from the A Development Fund, sanctioned by the Lords Commissioners of his Majesty's Treasury, to or through the Board of Agriculture and Fisheries, up to March 31, 1912, has recently been published as a Parliamentary Paper [Cd. 6252] (price $\mathrm{I}_{\frac{1}{2}} d$.). The subjoined extracts show the amounts and purposes of the grants.

\section{(I) Improvement of Light Horse Breeding.}

In Ig io the Board applied for an advance from the Development Fund in respect of a scheme for the improvement of light horse breeding, and in January of the following year the Treasury, on the recommendation of the Development Commissioners, sanctioned an advance of $39,800 l$. to be expended generally on the lines of the scheme proposed by the Board.

A further grant of a sum not exceeding $1250 l$. was also sanctioned to meet the expenses of administration. In August, I9II, the Treasury, on the recommendation of the Development Commissioners, sanctioned an advance of an additional sum not exceeding ro,oool. for allocation before March 31, I9I2, to enable county committees to purchase brood mares in time for the breeding season of 1912 , the original grant of Io,oool. having been allocated early in the financial year $191 \mathrm{I}-12$ for the purposes of the breeding season of rgrr.

The Treasury, on the recommendation of the Development Commissioners, has sanctioned an advance of $40,000 l$. or such part thereof as may be required in respect of the scheme, in the financial year $1912-13$.

\section{(2) Agricultural Research.}

\section{(i.) Interim Advances.}

The Board made an application for an advance of jo,oool. per annum from the Development Fund for the organisation of a system to aid and develop agriculture by promoting scientific research and experiment, and for the provision of technical aid and advice to agriculturists. The Treasury, on the recommendation of the Development Commissioners, has sanctioned an interim advance of such part of a sum of $9706 l$. as might be required in the financial year I9II-I2 for the purpose of making the following grants :-

No. 223 I, VOL. 89] 